ISAHP Article: Irawan, Sumarwan, Suharjo, Djohar/ Business Model of Tin Industry in Indonesia (Case Study Bangka Belitung Province) Proposals To Be Submitted to the International Symposium of the Analytic Hierarchy Process 2014, Washington D.C., U.S.A.

\title{
STRATEGIC MODEL OF TIN MINING INDUSTRY IN INDONESIA (CASE STUDY BANGKA BELITUNG PROVINCE) ${ }^{1}$
}

\author{
R. Rudy Irawan ${ }^{2}$ \\ Student of Graduate program of Management and Business \\ Bogor Agricultural University \\ Bogor, Indonesia \\ Ujang Sumarwan ${ }^{3}$ \\ Graduate program of Management and Business \\ Bogor Agricultural University, Indonesia \\ Budi Suharjo ${ }^{3}$ \\ Graduate program of Management and Business \\ Bogor Agricultural University, Indonesia \\ Setiadi Djohar ${ }^{3}$ \\ Graduate program of Management and Business \\ Bogor Agricultural University, Indonesia
}

\begin{abstract}
Indonesia has abundant natural resources such oil, gas and mineral. Bangka Belitung Province is one of abundant tin mineral and was mined in 1668. Beside, tin mining industry created conflict interest among stakeholder in Bangka Belitung. An aim our study was to make strategic model of tin mining industry which solved conflict among stakeholder in Bangka Belitung. Method was used in-depth interview expert in mining industry to create strategic model framework. Then, the study used tool analysis Analytical Network Process (ANP).
\end{abstract}

Keywords: strategic model, tin mining, ANP

${ }^{1}$ Paper is part of dissertation Graduate program of Management and Business, Bogor Agricultural University (MB-IPB)

${ }^{2}$ Student Doctoral program of Management and Business, Bogor Agricultural University (MB-IPB)

${ }^{3}$ Advisor committee of Management and Business, Bogor Agricultural University (MBIPB) 
IJAHP Article: Irawan, Sumarwan, Suharjo, Djohar/Business Model of Tin Mining Industry in Indonesia (Case Study: Bangka Belitung Province) Proposal To Be Submitted to the International Symposium of the Analytic Hierarchy Process 2014, Washington D.C., U.S.A.

\section{Introduction}

Brunnschweiler (2008) stated a positive relationship between the abundance of natural resources with economic growth. Indonesia is one of abundant natural resources which can be potential for economic growth. Bangka Belitung is province which has much tin mineral deposit; therefore, most local revenue Bangka Belitung comes from tin mining industry.

One of the problems in mining industry is the competition for mineral land use and degradation from mining activities (Casper 2007). Based on data from the Regional Environmental Agency (BLHD) Bangka Belitung province recorded that there are 991 pond in 2006 which comes from mining activity, while in 2010 about 65 percent of forest has been categorized as critical and damaged. Forest destruction has also occurred in the protected area by illegal mining. In addition, it was reported also major rivers are polluted mainly due to the turbidity of soil particles from washing tin ore into the rivers (BLDH 2012). This environmental damage is mainly impact for local communities and local government.

Illegal mining is one of problem in tin mining industry. One side, they give workforce for society and the other side, uncontrolled illegal mining cause a huge impact in environmental. Environmental damage caused by illegal tin mining has increased, especially since 1998 (Inonu 2010). Illegal mining affect the miner has no obligation to conduct post-mining land rehabilitation, as one obligation for miner which has mining license (Elfida 2007). Elfida (2007) stated that illegal miner has no interest to get license because there is no meaningful sanction from local government. Stakeholder local government can't control the presence of the tin miner. Besides an absence of evaluation and supervision of the local regulations relate to mining activities. Other studied stated also confirms that low of law enforcement for illegal mining in Bangka Belitung (Purba 2007).

Another problem in the tin mining industry in Indonesia is also linked lack of coordination between the local government and central government in regulation and licensing tin mining. A lot of different interpretation about regulation that make implementation didn't sync rule at various levels and sectors (Hayati 2011). Furthermore, there is social problem in tin mining. Tin mining company is rarely promote community participation in local (Aziz, Salim 2005) and the mining activity very closely with poverty, especially in areas that were directly related to mining exploitation activities (Jatam 2005). Evaluation from World Bank found that mining activities is lacking to contribute of poverty alleviation of local communities (EIR 2003). Besides, mining activities not only suspected because didn't contribute in promoting local community, but also triggered a variety of socio-economic conflicts (Resosudarmo, Subiman 2010; Erman 2013).

Power and interest between stakeholders for tin resources is also an issue mining industry in Indonesia. Transition era from a monopoly to a free market system has caused a lot of turbulence and conflict between stakeholders (Djaja 2012). Conflicts tin mining industry in Bangka Belitung is that many layers, not just a business conflict, but also political conflicts and power. Each stakeholder is finding arguments on legal issues and regulations for the political power and structures (Erman 2007; Resourdarmo et al 2009) Varying degrees of interest and power of each stakeholder involved in tin mining industry. Because of that we need a comprehensive strategic model tin mining industry 
IJAHP Article: Irawan, Sumarwan, Suharjo, Djohar/Business Model of Tin Mining Industry in Indonesia (Case Study: Bangka Belitung Province) Proposal To Be Submitted to the International Symposium of the Analytic Hierarchy Process 2014, Washington D.C., U.S.A.

which accommodates a wide range of stakeholders in order to resolve the existing problems in the tin mining industry in Indonesia. The approach of this study conducted with stakeholder management approach with in-depth and comprehensive analysis of the tin mining industry. The benefits of this approach may be to avoid conflict between stakeholders. In developing an appropriate strategic model, the industry needs to pay attention to the various stakeholders that influence the sustainability of the business.

\section{Literature Review}

The origins of the stakeholder theory began in 1984. Stakeholder theory describes the interactions and interconnections of the various stakeholders. At that time, Freeman defines stakeholders as a group or individual who can affect or is affected by the achievement of organizational goals (Freeman 1984:46). Thus, stakeholder theory focuses on the relationship between business and the groups and individuals who can affect or be affected by it. (Smudde and Coutright 2011). Freeman (1984:102) stated that there are five generic strategies to achieve objectives and accommodate the stakeholders. There are specific stakeholder's strategy, shareholders strategy, and utilitarian strategy rawlsian strategy social harmony strategy.

In developing a strategic model, industry need to pay attention to the various stakeholders that affect business sustainability. Based on Freeman et al (2007), business is an interaction with a set of relationships between groups with different interests in shaping the company's activities. Interaction with customers, suppliers, employees, investors, communities, and the other is which created value. Business need to understand how they are working for a business sustainable development.

\section{Hypotheses/Objectives}

An aim our study was to make strategic model of tin mining industry in Indonesia (case study Bangka Belitung) strategies in Indonesia's tin mining industry as solution to avoid conflicts between stakeholders, economic improvement, increasing regional revenue, and competitiveness tin industry.

\section{Research Design/Methodology}

Our methodologies conducted structured-in depth interviews and focus group discussion.. Expert respondents were selected by purposive sampling. Respondents were selected by non-probability sampling technique. Table 1 is a expert respondent to be used in the stakeholder interviews and FGD.

Table 1. Expert Respondent in Tin Mining Industry

\begin{tabular}{|l|l|}
\hline Name & Expert \\
\hline Ir. Wahid Usman, MBA & $\begin{array}{l}\text { Tin expert/Former President Director PT. Timah } \\
\text { Tbk }\end{array}$ \\
\hline Ir. Surawadi, MSc & $\begin{array}{l}\text { Tin expert/Former Exploration Director PT. } \\
\text { Timah Tbk }\end{array}$ \\
\hline Ir. Suryadi & $\begin{array}{l}\text { Tin expert/ Former Vice Governor Bangka } \\
\text { Belitung }\end{array}$ \\
\hline Dr. Bambang Setiawan & $\begin{array}{l}\text { Tin expert/ Former General Directorate of Energy } \\
\text { and Mineral (ESDM) }\end{array}$ \\
\hline Prof. Dr. Syoni Soepriyanto, MSc & Tin expert/academics/lecturer \\
\hline
\end{tabular}


IJAHP Article: Irawan, Sumarwan, Suharjo, Djohar/Business Model of Tin Mining Industry in Indonesia (Case Study: Bangka Belitung Province) Proposal To Be Submitted to the International Symposium of the Analytic Hierarchy Process 2014, Washington D.C., U.S.A.

\section{Data/Model Analysis}

Model was confirmed by expert tin mining industry. Framework ANP consists of 6 cluster which there are strategic model, macro-environment strategic, key stakeholder, activity, problem industry, and strategic. Framework ANP can be seen in below.

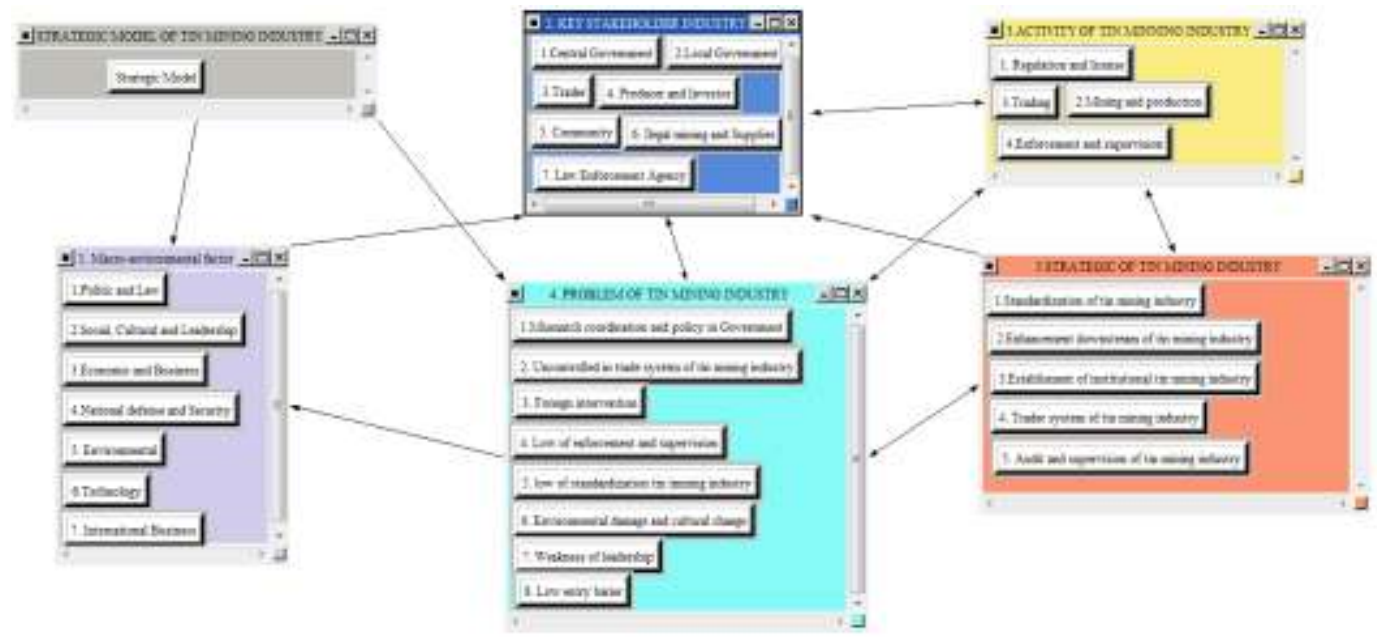

Figure 1. Framework ANP: Strategic Model of Tin Mining Industry in Indonesia (Case Study Bangka Belitung)

Priorities should be concerned in macro-environment is politic and law, key stakeholder is central government, key activities is regulation and license, problem should be finished a coordination, strategic is making institutional. Our model stated that regulation and government are major problem in Indonesia. One of solution is making powerful institutional which handle tin industry from upstream to downstream.

\section{Limitations}

Limitation research is a expert from government which is added. Further research suggests add a new cluster such as value proposition as objective model.

\section{Conclusions}

Our model can be used as solution to solve problem in Bangka Belitung. Major players should be concerned government as regulator. Regulation and license should be reviewed. ANP is a good solution to make model which can be used for practical in Bangka Belitung. Other cluster can be added as enrich model in ANP.

\section{Key References}

Azis IJ, Salim E. (2005) Development Performance and Future Scenarios in the Context of Sustainable Utilisation of Natural Resources. Di dalam: Resosudarmo BP editor. The Politics and Economics of Indonesia's Natural Resources; Singapura (SG): ISEAS. hlm 125-144 
IJAHP Article: Irawan, Sumarwan, Suharjo, Djohar/Business Model of Tin Mining Industry in Indonesia (Case Study: Bangka Belitung Province) Proposal To Be Submitted to the International Symposium of the Analytic Hierarchy Process 2014, Washington D.C., U.S.A.

Djaja H. (2012). Contestation of Actor in A Seizure of Tin Resource in Bangka. [Disertation] Bogor(ID): Institut Pertanian Bogor.

Freeman RE. (1984). Strategic management: A stakeholder approach. Boston(US): Pitman

Freeman et al. (2007). Managing for Stakeholders Survival, Reputation and Succes. New Haven (UK): Yale University Press

Saaty TL, Vargas LG. (2006). Decision Making with Analytic Network Process Economic, Ploitical, Social and Technological Applications with Benefits, Opportunitis, Cost and Risk. Pittsburgh (US):Springer Science 